\title{
AGENCY PROBLEMS AS A DRIVER FOR CRIME IN THE AEC-INDUSTRY
}

\author{
Jardar Lohne ${ }^{1}$, Frode Drevland ${ }^{2}$, and Ola Lædre ${ }^{3}$
}

\begin{abstract}
The paper seeks to outline agency problems as a fundamental driver for crime occurring in the AEC industry. The investigation uses Principal/Agent-theory to articulate how specific industry mechanisms serve as structural drivers of crime and how they can be counteracted.

This paper is conceptual, based on former empirical investigations - the approach springs from industry knowledge, extensive literature reviews and empirical research.

The research reveals that little discussion has been carried out concerning the root causes of criminal activity within the AEC industry. Widespread theoretical insights from economics and criminology can explain significant parts of the challenges. Production control efforts seem to be an auspicious path for combatting crime.

Being under-analysed to such a degree as identified, the theoretical conditions for criminal activity within the AEC industry needs more in-depth consideration. This need for further exploration especially concerns the implications of criminal activity on advanced process-driven production systems approaches. Establishing effective countermeasures depends heavily on such an understanding.
\end{abstract}

\section{KEYWORDS}

Process, supply chain management, production control, illegal actions, principal-agent theory.

\section{INTRODUCTION}

The threat posed by criminal activity - in its many forms, such as corruption, money laundering, and false materials - to the AEC (Architecture, Engineering, Construction) industry is underlined in several publications within the context of the Lean Construction (LC) community. Corruption results in - for example - reduced quality of the built facility, prolonged project delivery duration and increasing project prices (Rizk et al. 2018). False materials - known to exist in, for example, load-bearing systems (Kjesbu et al. 2017) can have serious consequences. In addition, criminal activity can be difficult to detect (Thameem et al. 2017). While the threat is well documented, the drivers of such activity are less understood, to the extent of constituting a hole in the general understanding of

Norwegian University of Science and Technology (NTNU), jardar.lohne@ntnu.no, orcid.org/0000$\underline{0002-2135-3468}$

2 Norwegian University of Science and Technology (NTNU), frode.drevland@ ntnu.no, orcid.org/00000002-4596-1564

$3 \quad$ Norwegian University of Science and Technology (NTNU), ola.laedre@ntnu.no, +47 91189938 , https://orcid.org/0000-0003-4604-8299 
the industry. The extent of the problem accentuates the need to understand these drivers as a prerequisite to forming effective countermeasures.

Estimating the level of shadowy activity within a field - be it an industry or a country - is notoriously tricky (Locatelli et al. 2020). Certain attempts have nonetheless been made. A recent report mapping criminal activity in the Norwegian AEC industry estimates that such activity involves turnover figures of approximately NOK 28 billion (Eggen et al. 2017). This number represents more than $5 \%$ of the total turnover for the industry, which for 2017 was NOK 558 billion according to Statistics Norway (2019). However, Eggen et al. (2017) do not include fraud and other criminal activities within the materials supply chain in their analysis, a figure CII (2014) estimated to a further approximately $10 \%$ of total turnover within the US context. Considering the AEC industry's international connectivity, it seems likely that the figures witnessed within the US context resemble those in Norway. Recent explorative studies indicate that Norwegian materials supply chains are subject to significant fraudulent behaviour (Engebø et al. 2016; Kjesbu et al. 2017a). Conservatively, it seems likely that criminal activity within the Norwegian context encompasses a two-digit percentage of the industry's total turnover. This number amounts to a typical national defence budget for Norway - for $2017-51$ billion NOK, according to the Norwegian Ministry of Defence (2016).

Based on reports from public agencies (e.g. Ministry of Labour and Social Affairs, 2015; Office of the Auditor General of Norway, 2015-16a; Office of the Auditor General of Norway, 2015-16b; Norwegian Ministries, 2017), industry reports (e.g. Slettebøe et al. 2003), and research analyses (e.g. Andersen et al. 2014), the common opinion seems to be that present control efforts towards countering crime do not stop an escalation of criminal activity in the Norwegian AEC industry. Recent research indicates that the criminal activity takes place in fields outside the present scope of the Norwegian control authorities (e.g. Engebø et al. 2016; Kjesbu et al. 2017a; Kjesbu et al. 2017b; Lohne et al. 2015; Lohne et al. 2017; Lohne et al. 2020; Richani et al. 2017; Skovly et al. 2017). These fields include supply chain management, use of false identities, and building process challenges, such as those occurring in the design and handover phases (Lohne et al. 2017; Lohne et al. 2020; Svalestuen et al. 2015).

This paper aims to articulate the relationship between acknowledged industry characteristics and the potential for criminal activity through the lens of Principal/agent (P/A) theory and to propose further crime-combatting measures based on this. These insights are neither ground-breaking nor very innovative, but we have not seen a thorough discussion of their implications for production-oriented approaches such as Lean Construction. This paper addresses the following three research questions:

1. What are the structural drivers for criminal activities in the AEC industry?

2. To what extent do findings from the Norwegian context correspond with these theoretical insights?

3. Based on the above, what measures can be envisaged for countering the criminal activity identified?

\section{METHODOLOGY}

This conceptual paper springs from empirical research carried out under the project «Mapping opportunities for criminal behaviour in the Norwegian AEC-industry», supported by Project Norway (projektnorge.no/krim). Over the years 2014-2020, the project has investigated the Norwegian construction industry, thereby permitting for 
research-based synthesis. The methods employed here are analytic in nature, and the approach is based on industry knowledge and earlier empirical research within the research project. Much of the analysis is based on a scoping literature review of criminal activities in the AEC industry reported in Lohne et al. (2019a). A narrow review of the specific challenges analysed in this paper was carried out September-December 2020. The main search engine used was Google Scholar. In addition, the library database Oria was used. Search terms included "principal agent", "construction industry", "AECindustry", "agency problems", "building process", "crime", and "supply chain management". The individual search terms returned more hits than possible to investigate; however, they returned manageable numbers of hits when combined.

So far, more than 220 semi-structured interviews and a major survey among Norwegian contractors have been carried out within this research project. A list of publications stemming from the project can be found on prosjektnorge.no/krim. When using findings from these interviews and this survey, a research limitation is that they were not solely about agency problems as drivers for criminal activity. While the paper is conceptual in nature, the conclusions presented here are nevertheless grounded in practical research.

\section{DRIVERS OF CRIME IN THE AEC-INDUSTRY}

A certain comprehension of what mechanisms drive criminal activity in the AEC industry appears to be widespread among practitioners in the form of tacit knowledge, as first described by Polanyi (1966). Among the studies concerned with crime, corruption has received the most attention. Interestingly, the very nature of AEC projects has arisen as a driver. For instance, Rizk et al. (2018) outline how "the complexity of the project and organisations involved coupled with scarce sanctions on corrupt activities" is a factor leading to corruption. However, much of this effort has described weaknesses in tendering processes, undue political involvement, insufficient sanctions, and similar matters. Little research document and analyse the conditions for criminal activity theoretically. Failing to do so leaves the understanding of crime at the level of symptom healing. In particular, few authors have addressed how industry characteristics serve as structural drivers for crime from a theoretical perspective. Understanding this is crucial for developing effective countermeasures.

\section{Structural Characteristics OF THE AEC-INDUSTRY}

The AEC industry is generally considered an industry of - in lieu of more subtle words low moral standing. Based on contributions from Ballard and Howell (1998) and Vrijhoef (2011), the research presented in this paper considers the following elements to such a reputation. These are generic and not referenced extensively. Firstly, there is a:

- A low technological entry point for industry actors

Actors barely possessing formal qualifications can enter the industry's value chains. Get a hammer, you're in construction! Secondly, the industry carries out the production of:

- Unique products («One-off’s»)

Construction projects are typically highly complex products delivered to serve a particular purpose. Therefore, non-standard solutions are common. Products being unique implies that control over the end-product is complex. This implication is underlined by, thirdly: 
- A significant number of clients within the industry are single-project clients

Being a single-project client renders the demand for control over the procurement and production processes highly challenging, especially when the project commissioned is not easily comparable to other projects. The lack of standardised production/standardised products increases the burden for single-product clients. Fourthly, there is:

- On-site production

One principal character of buildings is that they are - with very few exceptions stationary. Correspondingly, the production of buildings must take place in outdoor conditions. On-site production typically creates a lack of transparency concerning work conditions and other factors more easily controlled within fixed production conditions. Fifthly, AEC projects have:

- Unique project teams

Very rarely are project teams continued from project to project. New teams pose a significant challenge to the production process. The level of trust in such altering conditions is generally challenging since the potential to establish long-term relationships - on which trust typically depends - is limited. Finally, the AEC industry has:

- Complex, non-stable materials value chains

The number of different materials entering the building site has increased exponentially over the last century. Over the last decades, the internationalisation of trade - the materials' value chains are now truly international - has added to the complexity represented by an increasing number of building components. Also, the materials value chains are not stable, in that the particularities of each project typically introduce alterations to the former value chain. In sum, these concerns imply that controlling what materials enter the building site is inherently complex - and getting more so by each year. The research literature mostly ignores the importance of this insight. Exceptions from this general conclusion are, for example, Engeb $\emptyset$ et al. (2016), Engeb $\emptyset$ et al. (2017), Kjesbu et al. (2017a), Kjesbu et al. (2017b), Minchin et al. (2013) and CII (2014).

In sum, the AEC-industry a) has unique projects that b) are not easily measurable, c) are governed by inexperienced clients, d) with highly specific production sites, e) where the team changes from project to project, and f) where little efficient control is effectuated over the material value chains. These characteristics combined serve - we would argue as drivers for crime in the AEC industry. In the following, we propose to utilise insights from P/A-theory to capture more precisely what is at stake.

\section{Structural Characteristics in Light of Principal-Agent THEORY}

P/A-relationships occur when the "agent" (person or entity) make decisions or take actions on behalf of the "principal" (another person or entity) to advance the principal's goals (Milgrom and Roberts 1992). Examples of such relationships abound at least from early modernity in both fiction (e.g. the relationship between Othello (principal) and Iago (agent) in Shakespeare's Othello (Shakespeare, 1604 (1988)) and in non-fiction (e.g. the theoretical discussions in Machiavelli's The Prince (Machiavelli, 1532 (2011)) on the relationship between the ruler and his subjects). However, the challenges involved in such relationships seem first to have been labelled by their contemporary proper name by 
Jensen and Meckling (1976); most important within the analysis carried out in this paper is 1) goal incongruity, 2) information asymmetry, and 3) contract design.

Goal incongruity in the P/A-interaction arises when the agent and the principal have different or conflicting interests. As exemplified in Solheim-Kile et al. (2019), the agent's preference (wants as much payment as possible) regarding the performance of services does not correspond to the principal's preferences (wants it as cheap as possible).

Information asymmetry (in the context we are discussing) arises where agents possess information superior to that available to principals - concerning aspects such as own abilities and capabilities, financial situation, and local conditions. Information asymmetry exists when the principal and the agent have divergent interests, and the agent possesses information not available to the principal. Then the principal cannot assure that the agent is always acting in their (the principal's) best interest. This issue causes so-called agency costs (Bebchuk and Fried, 2004).

As Pouryousefi and Frooman (2019) have explained, the implications of these mismatches can prove problematic, given that it is the principal and not the agent that typically determines contract design. The principal is supposed to define the terms of the interaction between the parties involved in the contract. Still, both the goal incongruity and the information asymmetry hinder the transparency of the required interaction from the principal's perspective. If interest diverges, even if the principal makes contractual agreements with the agent, it is not sure that the agent delivers what she promises. Several contract tiers can increase interest divergence, for example, when the contractor select contractual arrangements with sub-contractors that diverge from the client's contract design. Then, the agent is likely to act contrary to the principal's interests. This interest typically results from asymmetrical incentive structures amongst the actors.

\section{Agency Problems Within the Norwegian AEC-INDUSTry}

The majority of design and build contracts carried out within the Norwegian AEC industry include some variant of the standard "NS 8407 General conditions of contract for design and build contracts". This standard regulates contractual relations when one agent (the design and build contractor) takes on all or a substantial proportion of the design and execution of building or civil engineering works (including construction, new build, maintenance, repair, and alterations) for a principal (the client).

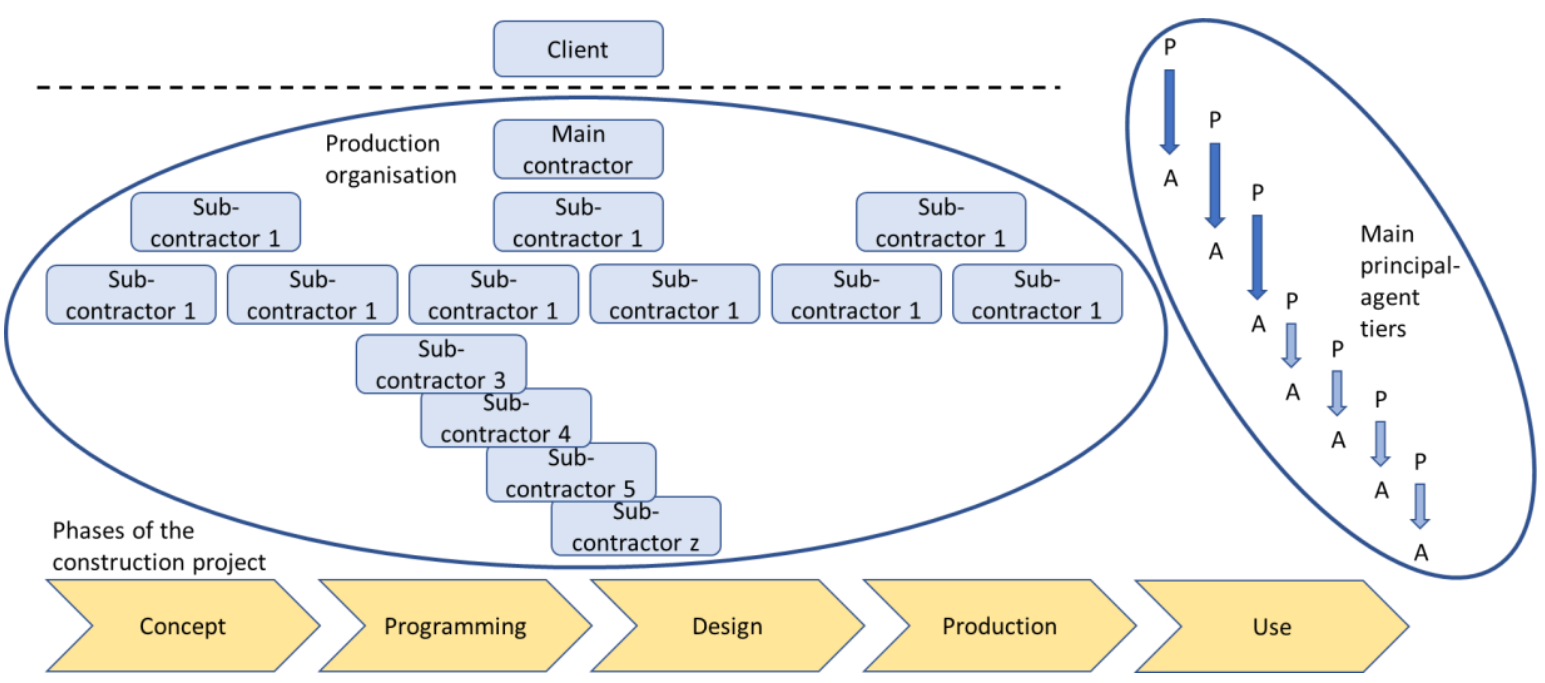

Figure 1: Outline of the production organisation of a typical construction project using NS 8407, with principal-agent tiers illustrated based on a generic phase structure. 
The Norwegian AEC industry relies heavily on the standard NS 8407. As illustrated by the dotted line in Figure 1, a prominent characteristic of the contract design is transferring risk from the client to the main contractor. This relationship represents the first of the P/A-tiers involved in such contracts. Further, the general tendency within the industrial context of Norway is to involve a series of sub-contractors to carry out the actual work on the project - these sub-contractors again typically employ sub-contractors, who in turn employ their own sub-contractors. The use of NS 8407 does not hinder the use of multiple layers of sub-contractors. The room for manoeuvre this leaves for criminal elements among sub-contractors is explored in Evjen et al. (2019).

Figure 1 illustrates the typical resulting situation, with multiple layers of subcontractors carrying out work. An extensive fragmentation of production organisation follows. According to the general outline of P/A-theory outlined above, this means that 1) there will probably be a lack of goal alignment between the sub-contractors and the project client; 2) that there will be a severe information asymmetry problem due to the organisational form of the project and that 3) this will probably mean that the client (dependent on the number of levels of sub-contractors involved) will have little to no information of what actually happens at the level of the organisation where actual physical work is carried out - including being aware or not of criminal activity. Gunnerud et al. (2019) explore opportunistic behaviour from project managers following such an analysis. As Lohne et al. (2019b) illustrated, this fuzzy landscape can serve project clients quite well - they benefit from criminal activity that they do not know of.

Skovly et al. (2017) present an interesting counterargument to this general statement within the Norwegian context. Their analysis clearly illustrates that the client has significant potential for rendering the sub-contractors' accountability transparent through active crime-preventive measures. However, such initiatives are rare in Norway, and the literature review conducted in preparing the research presented in this paper indicates that such measures are also rare internationally. The effort needed to carry out this initiative equally illustrates another general insight from P/A-theory, notably that of information as a commodity, leading to that principals "can invest in information systems in order to control agent opportunism" (Eisenhardt, 1989:64).

\section{Measures For Countering Criminal ACTIVITy}

At least three lines of measures can counter the drivers for criminal activities: 1) precautions in the contract, 2) control efforts - possibly carried out by a third party, and 3) production control.

Firstly, it is possible to adjust contract design and manage contracts to reduce agency problems occurring. Initiatives in Norway have explored the consequences of reducing the project organisation's complexity by allowing the main contractor to have a maximum of two subcontractor tiers. Such adjusted contract design - with only subcontractors and sub-sub-contractors - are explored in Aure et al. (2020). The main challenge to their efficiency seems to be the challenges of reducing project organisations' complexity, given the endeavour's complexity, see Haugen et al. (2017). Gunnerud et al. (2019) found that even though the contracts intend to restrict the possibilities for criminal activities, project managers have substantial room for manoeuvre for criminal activities.

Secondly, within the Norwegian context, a significant weight has been put on legislation and control efforts targeting criminal activities in the AEC industry. Legislation in general and control efforts initiated by official agencies have concentrated almost exclusively on the last tier of subcontractors. Few efforts envisaged rendering 
main contractors or clients responsible for criminal activity has so far been observed. The research project has conducted a series of explorative attempts (reported on at prosjektnorge.no/krim) to assess the legislation's actual effectiveness and corresponding measures. However, it has proved challenging to understand to which degree - if at all these have had any real impact. The interest in governance measures witnessed over the last years can potentially indicate that control efforts are taken seriously by both clients and contractors. So far, Skovly et al. (2017) concluded that even though the Norwegian authorities have introduced new legislation at the same time as both clients and contractors show interest on governance level, there is still substantial room for manoeuvre.

Thirdly, production control can help project clients and main contractors to achieve predictability and transparency in their projects. Within standard P/A-theory, such measures fall under the heading information systems. As Eisenhardt maintains, "the more programmed the task, the more [...] information about the agent's behaviour is more readily determined. Very programmed tasks readily reveal agent behaviour" (1989:62). A very high level of tasks programming is readily observable within the LC literature, especially at the production level. LC contains sets of production control tools, such as the Last Planner ${ }^{\circledR}$ System, Takt planning and IPD. These tools, which rely on project planning, increase predictability and - most notably within this context - transparency in projects. Further, again from Eisenhardt, "it seems reasonable that when principals and agents engage in a long-term relationship, it is likely that the principal will learn about the agent $[. .$.$] and so will be able to assess behaviour more readily" (ibid.). The call for$ long-term P/A-relationships stands out as a true leitmotif within the LC literature. These insights, in sum, enables us to conclude with Eisenhardt that "since information systems inform the principal about what the agent is actually doing, they are likely to curb agent opportunism because the agent will realise that he or she cannot deceive the principal" (1989:60). Programmed tasks lead to transparency and thus potentially reduces the level of deceitful actions.

\section{DISCUSSION AND CONCLUSION}

In this paper, we have addressed structural drivers for criminal activities within the AEC industry, examined to what extent findings from the Norwegian context correspond with these theoretical insights and outline three lines of measures for countering the criminal activity identified. The analysis indicates that Norwegian AEC projects share characteristics with internationally recognised issues concerning technological entry point, uniqueness of projects etc. As previously discussed, the persistence of these traits is underlined by the common use of NS 8407, leaving much room for manoeuvre for subcontracting. Resulting from this conjuncture of product specificities and (contractual) organisation is significant, inherent agency problems. Such problems lead to a situation where it is very difficult for the client to know with any certainty what the last-tier subcontractor is doing. This situation appears to leave the room for manoeuvre for criminal actors wide open.

The three lines of measures discussed for countering criminal activities in the AEC industry are 1) contract design and contract management, 2) laws and control efforts, and 3 ) production control. The two first have room for manoeuvre that rotten apples can exploit. Project managers can surpass the current contract management regime's parts targeted at combating criminal activities initiated by clients. Likewise, project managers that want to do so can surpass legislation and the corresponding control efforts initiated 
by official agencies. Thus, measures related to contract design and contract control are insufficient to combat criminal activities in the AEC industry. As long as rotten apples in the industry consider criminal activities to pay off, they will use the possibilities caused by characteristics such as low technological entry point, unique products, single product clients, and on-site production. Production control achieved through Lean Construction tools such as LPS, Takt planning, and IPD can increase project transparency.

\section{REFERENCES}

Andersen, R.K., Eldring, L. and Roed Steen, J. (2014). Privatmarkedet i byggenæringen - Usynlig arbeidsmarked i de tusen hjem. FAFO, Oslo.

Aure, B., Lædre, O., Lohne, J. (2020). "Experiences from Allowing Maximum Two Contract Tiers in the Vertical Supply Chain". Proc. $28^{\text {th }}$ Annual conference IGLC, Berkeley, 613-624.

Ministry of Labour and Social Affairs (2015). Strategi mot arbeidslivskriminalitet. Oslo. https://www.regjeringen.no/contentassets/4f7ae70171bd480682b8dafddadaf311/stra tegi_mot_arbeidslivskriminalitet.pdf, consulted 24.02.21.

Ballard, G. and Howell, G. (1998). "What kind of production is construction?". Proc. 28th Annual conference IGLC, Guaruja, Brazil.

Bebchuk L. and Fried, J. (2004). Pay Without Performance: The Unfulfilled Promise of Executive Compensation. Harvard University Press, Massachusetts.

CII (2014). Mitigating threats of counterfeit materials in the capital projects industry. CII Research Report No. 307-11, Austin, Texas.

Eggen, F.W., Gottschalk, P., Nymoen, R., Ognedal, T. and Rybalka, M. (2017). Analyse av former, omfang og utvikling av arbeidslivskriminalitet. Rapport nr. 69-2017, Samfunnsøkonomisk analyse AS, Oslo.

Eisenhardt, K. M. (1989). "Building theories from case study research". Academy of Management Review, 14(4) 532-550.

Engebø, A., Lohne, J., Rønn, P-E. and Lædre, O. (2016). "Counterfeit Materials in the Norwegian AEC-Industry". Proc. 24 ${ }^{\text {th }}$ Annual conference IGLC, Boston, p. 13-22.

Engeb $\varnothing$, A., Kjesbu, N., Lædre, O., and Lohne, J. (2017). "Perceived consequences of counterfeit, fraudulent and sub-standard construction materials". Procedia engineering, 196, 343-350.

Evjen, S., Gunnerud, G., Lædre, O., Søfting, R. and Lohne, J. (2019). "Sub-Contractors' Perception of Contracting: The Case of Crime". Proc. $10^{\text {th }}$ Nordic Conference on CEO. Emerald Group Publishing Limited, 59-671.

Green, SD and May, S.C. (2003). "Re-engineering construction: Going against the grain". Building Research and Information, 31(2) 97-106.

Gunnerud, G., Evjen, S., Søfting, R., Lædre, O., Kjesbu, N.E. and Lohne, J. (2019). "Project Managers: Gatekeepers or Inside Men?". Proc. 10 ${ }^{\text {th }}$ Nordic Conference on CEO. Emerald Group Publishing Limited, 69-75.

Jensen, C. and Meckling, W. (1976). "Theory of the firm: Managerial behaviour, agency costs and ownership structure". Journal of Financial Economics, 3(4) 305-360.

Haugen, A., Wondimu, P., Lohne, J. and Lædre, O. (2017). "Project delivery methods in large public road projects - a case study of E6 Jaktøyen-Sentervegen”. Procedia Engineering, 196, 391-398.

Kjesbu, N.E., Engebø, A., Lædre, O. and Lohne, J. (2017a). "Counterfeit, Fraudulent and Sub-Standard Materials: The Case of Steel in Norway". Proc. $25^{\text {th }}$ Annual conference IGLC, Crete, Greece, 805-812. 
Kjesbu, N.E., Engebø, A., Lædre, O. and Lohne, J. (2017b). "Countering counterfeit, fraudulent and sub-standard materials in construction: Countermeasures to avoid the use of counterfeit, fraudulent and sub-standard steel materials in the Norwegian construction industry". Proc. 30 ${ }^{\text {th }}$ Annual conference IPMA, Kazakhstan, 103-110.

Locatelli, G., Geraldi, J., Konstantinou, E. and Sainati, T. (2020). "The Dark Side of Projects: Uncovering Slavery, Corruption, Criminal Organisations, and Other Uncomfortable Topics". Special issue, call for papers, Project Management Journal. https://journals.sagepub.com/pb-assets/cmscontent/PMX/SI\%20Dark-PMJLONG(3).pdf, accessed 24.02.21.

Lohne, J., Shirkavand, I., Firing, M., Schneider, K., Lædre, O. (2015). "Ethics in Commissioning in Construction". Procedia Economics and Finance, 21, 256-263.

Lohne, J., Svalestuen, F., Knotten, V., Drevland, F. and Lædre, O, (2017). "Ethical behaviour in the design phase of AEC projects". International Journal of Managing Projects in Business, 10 (2) 330-345.

Lohne, J., Kjesbu, N.E., Engebø, A., Young, B. and Lædre, O. (2019a). "Scoping literature review of crime in the AEC industry". Journal of Construction Engineering and Management, 145 (6) 1-14.

Lohne, J., Drevland, F. and Lædre, O. (2019b). "Who Benefit from Crime in Construction? A Structural Analysis". Proc. 10 ${ }^{\text {th }}$ Nordic Conference on CEO. Emerald Group Publishing Limited, 163-170.

Lohne, J., Engeb $\varnothing$, A. and O. Lædre (2020). "Ethical challenges during construction project handovers". International Journal of Project Organisation and Management, 12(1) 31-53.

Machiavelli, N. (1532 (2011)). The Prince. Penguin Classics, UK.

Milgrom, P. and Roberts, J. (1992). Economics, organisation and management. Prentice Hall, Upper Saddle River, USA.

Minchin, R. J., Cui, S., Walters, R., Issa, R. and Pan, J. (2013). "Sino-American Opinions and Perceptions of Counterfeiting in the Construction Supply Chain". Journal of Construction Engineering and Management, 139, 1-8.

Norwegian Ministries (2017), Strategi mot arbeidslivskriminalitet, https://www.regjeringen.no/contentassets/17f35b6ba95f4da2a7ac4682b0a052af/no/p dfs/revidert-strategi-mot-arbeidslivskriminalitet-2021.pdf, consulted 24.02.21.

Norwegian Ministry of Defence (2016). Prop. 1 S (2016-2017). Proposisjon til Stortinget. https://www.regjeringen.no/contentassets/186c695600eb4db085dfcf2ca6825e49/no/ pdfs/prp201620170001_fddddpdfs.pdf, accessed 14.01.21.

Pasquire, C., Sarhan, S. and King, A. (2015). "A Critical Review of The Safeguarding Problem in Construction Procurement: Unpicking the Coherent Current Model". Proc. $23^{\text {rd }}$ Annual conference IGLC, Perth, Australia, 309-318.

Polanyi, M. (1966). The tacit dimension. Peter Smith Publisher, Gloucester, England.

Pouryousefi, S. and Frooman, J. (2019). "The consumer scam: an agency-theoretic approach". Journal of Business Ethics, 154 (1) 1-12.

Office of the Auditor General of Norway (2015-16a). Riksrevisjonens undersøkelse av myndighetenes arbeid mot sosial dumping ved offentlige anskaffelser. Dokument 3:14 (2015-2016), https://www.prosjektnorge.no/wpcontent/uploads/2017/11/sosialdumping-krim-BAE.pdf, consulted 24.02.21.

Office of the Auditor General of Norway (2015-16b). Riksrevisjonens unders $\varnothing$ kelse av myndighetenes innsats mot arbeidsmiljøkriminalitet. Dokument 3:15 (2015-2016), 
https://www.prosjektnorge.no/wp-content/uploads/2017/11/arbeidsmiljokriminalitetkrim-BAE.pdf, consulted 24.02.21.

Richani, Y., Klakegg, O.J., Lohne, J. (2017). "Drivers and consequences of identity abuse in the AEC-industry". Procedia Computer Science, 121, 337-344.

Rizk, R., Sobh, D., Abou Yassin, A. and Hamzeh, F. (2018). "Studying the mindset of corruption in the construction industry- A Lean Perspective." Proc. 26 ${ }^{\text {th }}$ Annual conference IGLC, Chennai, 316-325.

Sarhan, S., Pasquire, C.L., Manu, E. and King. A. (2016). "Are Tier-one contractors making their money out of wasteful procurement arrangements?" Proc. $24^{\text {th }}$ Annual conference IGLC, Boston, 83-92.

Shakespeare, W. (1604 (1988)). Four Tragedies: Hamlet, Othello, King Lear, Macbeth. Bantam Books, UK.

Shirkavand, I., Lohne, J. and Lædre, O. (2016). "Defects at handover in Norwegian construction projects". Procedia Social and Behavioral Sciences, 226, 3-11.

Skovly, M., Mørenskog, A.R., Engebø, A., Lædre, O. and Lohne, J. (2017). "Measures to counteract work-related crime - airport developments in Norway". Procedia Computer Science, 121, 664-671.

Slettebøe, A., Buseth, H., Gangås, B., Wold, E., Mo, N., Melleby, S. and Anskau, E. (2003). Seriøsitet i byggenæringen. FAFO, Oslo.

Solheim-Kile, E., Lædre, O. and Lohne, J. (2019). "Public-Private Partnerships: Agency Costs in the Privatisation of Social Infrastructure Financing". Project Management Journal, 50(2) 144-160.

Statistics Norway (2019). Strukturstatistikk for bygge- og anleggsvirksomhet, 2017. https://www.ssb.no/stbygganl, consulted 14.01.2021.

Svalestuen, F., Lohne, J., Knotten, V. and Lædre, O. (2015). "Ethics of the Design Phase - a Descriptive Approach". Proc. $23^{\text {rd }}$ Annual conference IGLC, Perth, Australia, 609618.

Thameem, M., Rybkowski, Z. K. and Smith, J. P. (2017). "Delivery Methods and Social Network Analysis of Unethical Behavior in the Construction Industry." Proc. $25^{\text {th }}$ Annual conference IGLC, Crete, Greece, 453-461.

Vrijhoef, Ruben (2011). Supply chain integration in the building industry - The emergence of integrated and repetitive strategies in a fragmented and project-driven industry. Delft University Press. 